\title{
Assessment of feto-maternal outcomes in preeclampsia and HELLP cases
}

\author{
Burcu Artunç Ülkümen, Halil Gürsoy Pala, Filiz Aktenk, Yeşim Bülbül Baytur \\ Department of Obstetrics \& Gynecology, Faculty of Medicine, Celal Bayar University, Manisa, Turkey
}

\begin{abstract}
Objective: In this study, our aim was to analyze the feto-maternal outcomes in pregnancies with preeclampsia and HELLP syndrome followed up at our clinic.

Methods: The data files of the cases with preeclampsia and HELLP syndrome who admitted to our clinic during 2011 and 2013 were evaluated retrospectively.

Results: The mean maternal age was $30.08 \pm 5.33$ in the preeclamptic group and $31.46 \pm 5.95$ in the HELLP syndrome group, respectively ( $\mathrm{p}=0.432)$. There was no significant difference between two groups regarding the gestational week during labor and fetal birth weight $(\mathrm{p}=0.185$ and $\mathrm{p}=0.060$ respectively). Intrauterine growth retardation was significantly more common in HELLP group $(\mathrm{p}=0.033)$ in terms of gestational complications. The transfusion of blood products was needed more commonly in HELLP group $(\mathrm{p}=0.023)$. Platelet levels were significantly lower and serum transaminases were significantly higher in HELLP group $(\mathrm{p}=0.001$ and $\mathrm{p}=0.038$, respectively).

Conclusion: Preeclampsia and HELLP syndrome are still severe obstetric complications leading to maternal and fetal morbidity and mortality. It would be reasonable to transport these cases to multidisciplinary centers having intensive care units.
\end{abstract}

Keywords: Preeclampsia, HELLP syndrome, maternal morbidity-mortality.

\section{Introduction}

Preeclampsia is a clinical spectrum appearing after 20 weeks of gestation and characterized with hypertension and concomitant proteinuria. Proteinuria is defined $300 \mathrm{mg}$ or above in the urine for 24 hours, or as $\geq 30$

\section{Özet: Preeklampsi ve HELLP olgularında} feto-maternal sonuçların değerlendirilmesi

Amaç: Bu çalı̧̧mada, kliniğimizde takip edilen preeklamptik ve hemoliz, yüksek karaciğer enzimleri, düşük trombosit (HELLP) sendromlu gebeliklerin fetal ve maternal sonuçlarının değerlendirilmesi amaçlanmıștır.

Yöntem: 2011-2013 yılları arasında kliniğimizde takip edilen preeklampsi ve HELLP sendromlu olgular dosya kayitlarından retrospektif olarak incelenerek gebelik sonuçları değerlendirildi.

Bulgular: Preeklampsi olgularımızın ortalama maternal yaşı $30.08 \pm 5.33$ iken HELLP sendromu olgularımızın maternal yaşı $31.46 \pm 5.95$ olarak tespit edildi $(\mathrm{p}=0.432)$. Her iki grup arasında doğum haftaları ve doğum kiloları açısından istatistiksel anlamlı fark saptanmadı (sırası ile $\mathrm{p}=0.185$ ve $\mathrm{p}=0.060$ ). Gebelik komplikasyonla$\mathrm{r} 1$ açısından incelendiğinde, intrauterin gelişme geriliği (IUGR) bulgusu HELLP sendromu olgularında anlamlı olarak daha sı izlendi $(\mathrm{p}=0.033)$. Kan transfüzyon gerekliliği HELLP sendromu grubunda anlamlı olarak daha sik izlendi $(\mathrm{p}=0.023)$. HELLP grubunda trombosit değerleri anlamlı derecede düşük ve serum transaminazları anlamlı derecede yüksekti (sırası ile $\mathrm{p}=0.001$ ve $\mathrm{p}=0.038$ ).

Sonuç: Preeklampsi ve HELLP sendromu günümüzde halen maternal ve fetal morbidite ve mortaliteye neden olan ciddi bir obstetrik komplikasyondur. Bu gebeliklerin yoğun bakım üniteleri bulunan multidisipliner merkezlere sevki uygun yaklaşım olacaktır.

Anahtar sözcükler: Preeklampsi, HELLP, maternal morbiditemortalite.

$\mathrm{mg}$ or $\geq 1+$ in the spot urine sample taken at least twice within maximum 7 days at 4-6 hours of intervals. Hypertension defines tension values over 140/90 $\mathrm{mmHg}$ in at least two measurements within maximum 7 days at 4-6 hours of intervals. ${ }^{[1]}$ The values become
Correspondence: Halil Gürsoy Pala, MD. Celal Bayar Üniversitesi Tip Fakültesi Kadın Hastalıkları ve Doğum Anabilim Dalı, Manisa, Turkey. e-mail: gursoypala@yahoo.com

Received: November 26, 2013; Accepted: January 6, 2014
Available online at: www.perinataljournal.com/20140222001 doi: $10.2399 /$ prn.14.0222001 QR (Quick Response) Code: 
normal within postpartum 6 weeks. Its incidence rate varies according to population examined, but it approximately ranges between 2 to $7 \% \cdot{ }^{[2]}$ It may cause maternal morbidity and mortality associated with complications such as pulmonary edema, intraventricular bleeding, intraventricular hemorrhage, and disseminated intravascular coagulation (DIC), as well as neonatal morbidity and mortality due to complications such as intrauterine growth retardation and premature labor. ${ }^{[3]}$ Neonatal and maternal mortality rates may reach up to $25 \%$ especially in early-onset severe cases. ${ }^{[4]}$

The syndrome of hemolysis, elevated liver enzymes, and low platelet count (HELLP) is a variant of preeclampsia according to some authors while another group of authors believe that it is completely a different pathology. ${ }^{[5]}$ HELLP syndrome is characterized with hemolysis, elevated liver enzymes and low platelet count, and it may appear at any week of gestation. The risk of fetal loss may reach up to $15 \% .{ }^{[6]}$ In this study, we aimed to analyze in the fetal and maternal outcomes in pregnancies followed up at our clinic with the diagnosis of preeclampsia and HELLP syndrome, and to evaluate in the light of the literature

\section{Methods}

The medical files of 40 cases with preeclampsia and 13 cases with HELLP syndrome who were followed at our clinic between January 2011 and December 2013 were evaluated in terms of fetal and maternal outcomes. Proteinuria $(300 \mathrm{mg}$ or above in the urine for 24 hours, or as $\geq 30 \mathrm{mg}$ or $\geq 1+$ in the spot urine sample taken at least twice within maximum 7 days at 4-6 hours of intervals) and hypertension (over 140/90 $\mathrm{mmHg}$ in at least two measurements within maximum 7 days at 4-6 hours of intervals) occurring after 20 weeks of gestation were considered as the criteria for preeclampsia diagnosis. In the diagnosis of HELLP syndrome, the findings of elevated liver enzymes, thrombocytopenia and hemolysis confirmed by peripheral smear were used. Data such as maternal age, gravida, parity were reviewed from medical records and week of gestation, maternal complications and fetal complications during diagnosis were evaluated. The approval of local ethics committee was obtained for the study.

\section{Results}

A total of 40 cases with preeclampsia and 13 cases with HELLP syndrome were included to our study. Mean maternal age of the cases with preeclampsia was $30.08 \pm 5.33$ while it was $31.46 \pm 5.95$ in the cases with HELLP syndrome ( $\mathrm{p}=0.432)$. There was statistically no difference between the groups in terms of gravida and parity (Table 1). Weeks of gestation during labor was $34.45 \pm 4.05$ in the preeclampsia group and $32.77 \pm 3.44$ in the HELLP syndrome group, and the difference was statistically not significant $(\mathrm{p}=0.185)$. While mean birth weight was $1737.50 \pm 679.19 \mathrm{~g}$ in the preeclampsia group, it was found as $2210.95 \pm 761.06 \mathrm{~g}$ in the HELLP syndrome group $(\mathrm{p}=0.060)$. In terms of gestational complications, the finding of intrauterine growth retardation (IUGR) was significantly more common in the cases with HELLP syndrome $(\mathrm{p}=0.033)$. The transfusion of blood products was needed significantly more commonly in HELLP group ( $\mathrm{p}=0.023$ ) (Table 2). All of the cases gave cesarean delivery. In terms of the previous cesarean rates, 12 cases in the preeclampsia group and 3 cases in the HELLP syndrome undergone cesarean delivery previously; in other words, $70 \%$ of the cases in preeclampsia group and approximately $77 \%$ of the cases in HELLP syndrome group had cesarean due to the primary indications of preeclampsia and HELLP syndrome. In terms of laboratory values, platelet values of

Table 1. Demographic characteristics of the cases.

\begin{tabular}{lccc} 
& Preeclampsia & HELL & p value \\
Maternal age $($ mean \pm SD) & $30.08 \pm 5.33$ & $31.46 \pm 5.95$ & 0.432 \\
Gravida (mean \pm SD) & $2.33 \pm 1.24$ & $2.30 \pm 1.38$ & 0.950 \\
Parity (mean \pm SD) & $1.07 \pm 0.93$ & $1.0 \pm 0.28$ & 0.801 \\
Weeks of gestation $($ mean \pm SD) & $34.45 \pm 4.05$ & $32.77 \pm 3.44$ & 0.185 \\
\hline
\end{tabular}

Table 2. Preeclampsia cases vs. cases with HELLP syndrome in terms of antenatal complications.

\begin{tabular}{lccc} 
& $\begin{array}{c}\text { Preeclampsia } \\
\mathrm{n}=\mathbf{4 0}\end{array}$ & $\begin{array}{c}\text { HELLP } \\
\mathrm{n}=\mathbf{1 3}\end{array}$ & p value \\
GDM & 2 & - & 0.559 \\
Anemia & 22 & 7 & 0.962 \\
Oligohydramnios & 8 & 7 & 0.061 \\
IUGR & 5 & 6 & 0.033 \\
Blood transfusion & 18 & 11 & 0.023 \\
Ablatio placentae & 4 & 4 & 0.185 \\
IFD & 1 & 2 & 0.063 \\
\hline
\end{tabular}

GDM: Gestational diabetes mellitus, IUGR: Intrauterine growth retardation, IFD: Intrauterine fetal death 
the cases in HELLP group were significantly higher $(p=0.001)$ and liver enzymes were significantly higher $(\mathrm{p}=0.038)$ (Table 3$)$.

\section{Discussion}

Preeclampsia is frequently seen in primigravida cases. However, in our study, it was found out that only about $27.5 \%(n=11)$ of the cases in preeclampsia group was primigravida. In multipara patients being preeclampsia in their previous pregnancy, partner change or the duration between two pregnancies being short (less than 2 years) are the major factors increasing the risk. ${ }^{[7]}$ However, since our study was retrospective, we could not obtain detailed data from the medical records of multipara patient group. Another misleading condition about the rates is that our clinic is a tertiary center, and there may be admissions from surrounding cities and counties. In the cases with HELLP, we found that $38.5 \%(n=5)$ of the cases were primigravida pregnancies. Although the pathophysiology of HELLP syndrome is not clear, it is frequently seen in multipara pregnancies. ${ }^{[6]}$ The mean age tends to be higher than preeclamptic pregnants (usually $>25$ years old) ${ }^{[6]}$ While mean maternal age was $30.08 \pm 5.33$ for preeclampsia cases in our study, it was found as a little higher in the cases with HELLP syndrome which was 31.46 \pm 5.95 . However, this difference was statistically not significant $(\mathrm{p}=0.432)$.

HELLP syndrome complicates about $0.2-0.7 \%$ of pregnancies. Superimposed HELLP syndrome is observed in about $4-12 \%$ of cases with preeclampsia or eclampsia. ${ }^{[5]}$ Another issue that should be considered is that there may be no hypertension in approximately 10$15 \%$ of the patients, so this condition may cause latency in diagnosis and intervention. ${ }^{[8]}$ In the diagnosis of the cases especially presented out of the ordinary, most specific indicator for HELLP syndrome is platelet count. Therefore, if any decrease is detected in the platelet count during antenatal follow-up, HELLP syndrome should be considered certainly. ${ }^{[9]}$ In our study, platelet values were significantly lower in HELLP group $(\mathrm{p}=0.001)$. Serum transaminase values may reach up to $4000 \mathrm{U} / \mathrm{L} .{ }^{[6]}$ As long as DIC does not develop as well, coagulation profile (prothrombin time) progresses at normal levels. However, in cases where fibrinogen levels are less than $300 \mathrm{mg} / \mathrm{dl}$, DIC development should be suspected. ${ }^{[6]}$ Also, in the studies performed, it was seen that positive $\mathrm{D}$-dimer test shown the development of HELLP syndrome even there was no deterioration in other coagulation parameters. ${ }^{[6]}$
HELLP syndrome and preeclampsia are associated with maternal and fetal morbidity and mortality. ${ }^{[10]}$ Also, its clinical progress is rapid and disseminated intravascular coagulation may be seen within hours. ${ }^{[1]}$ In a compilation study arranged by Haram et al., it was found that eclampsia was between 4 and $9 \%$, ablatio placentae between 9 and $20 \%$, DIC up to $56 \%$ as the maternal complications associated with HELLP syndrome. ${ }^{[10]}$ In our study, ablatio placentae rate was $30 \%(n=4)$ in the HELLP group while it was $10 \% \quad(n=4)$ in the preeclampsia group. However, this difference was statistically not significant (Table 2). DIC developed in 2 cases in the HELLP group. There was no DIC in preeclamptic group $(\mathrm{p}=0.002)$. It was reported the rate of IUGR in the cases with HELLP syndrome reached up to $60 \%(10,12)$. In line with the studies performed, we found IUGR rate as $50 \%(\mathrm{n}=6)$ in the HELLP group. This rate was significantly different than the rate found in preeclampsia group $(\mathrm{p}=0.033)$. It was emphasized that HELLP syndrome accompanied perinatal mortality up to the rates of $35 \% .^{[10]}$ In Turkey, in a study performed by Gezginc et al., intrauterine fetal mortality was found as $10.4 \% .{ }^{[3]}$ In our study, in utero fetal loss was found as $15 \%(\mathrm{n}=2)$ in HELLP syndrome. Maternal mortality rate associated with HELLP syndrome is reported between 1 and $24 \% .{ }^{[10]}$ Acute renal failure (ARF), DIC, and cerebral hemorrhage are major mortality reasons. In case of acute renal failure associated with pregnancy, the most common underlying reason is HELLP syndrome. ${ }^{[10]}$ In the study performed by Sibai et al., it was highlighted that ARF was observed at a rate of $7.3 \%$ with HELLP. ${ }^{[13]}$ In a study carried out on 14 cases with HELLP syndrome, ARF developed in a case. ${ }^{[14]}$ Similar to these rates, one of our cases with HELLP syndrome developed ARF (7\%).

Table 3. Comparison of laboratory findings of cases with preeclampsia and HELLP syndrome.

\begin{tabular}{lccc} 
& $\begin{array}{c}\text { Preeclampsia } \\
\mathbf{n}=\mathbf{4 0}\end{array}$ & $\begin{array}{c}\text { HELLP } \\
\mathbf{n}=\mathbf{1 3}\end{array}$ & p value \\
Platelet & $85459 \pm 30321$ & $53153 \pm 18636$ & 0.001 \\
Hemoglobin & $12.07 \pm 1.18$ & $10.58 \pm 2.32$ & 0.656 \\
Hematocrit & $29.08 \pm 5.83$ & $30.30 \pm 6.19$ & 0.526 \\
AST & $143.22 \pm 333.41$ & $406.08 \pm 495.33$ & 0.038 \\
ALT & $75.94 \pm 187.10$ & $223.31 \pm 277.70$ & 0.039 \\
Creatinine & $0.81 \pm 0.386$ & $1.01 \pm 0.485$ & 0.142 \\
Uric acid & $6.08 \pm 1.40$ & $6.10 \pm 1.23$ & 0.968 \\
\hline
\end{tabular}


Also, preeclampsia and HELLP syndrome increase neonatal morbidity and mortality associated with prematurity due to delivery requirements. In a study, it was reported that premature labors are observed at a rate of $70 \%$ in HELLP syndrome. ${ }^{[15]}$ In our study, premature labor rate was found as $72 \%$ in the preeclampsia group. This rate was found as $90 \%$ in the HELLP group. While delivery occurred at an early week in the HELLP group, the week of gestation during delivery was not statistically significant between two groups.

There are no certain limits related with the delivery type in preeclampsia and HELLP syndrome cases. The week of gestation that the disease is detected, general condition of patient and the progress of disease, availability of experienced personnel for delivery and anesthesia are the major parameters impacting the delivery type. ${ }^{[10]}$ In cases where maternal hypertension cannot be controlled, the findings of ablation develop, fetal distress findings appear and maternal laboratory findings deteriorate, cesarean would be a reasonable preference. ${ }^{[12]}$ Cesarean should be preferred also in the presence of HELLP syndrome before 30 weeks of gestation, oligohydramnios, IUGR and in the presence of non-conforming Bishop score. ${ }^{[15]}$ What matters here is to apply platelet suspension support to patients who have platelet values of $50.000 / \mathrm{mm}^{3}$ and planned for cesarean, and to patients who have platelet values of $25.000 / \mathrm{mm}^{3.16]}$

\section{Conclusion}

In our study, the case group with HELLP syndrome is relatively higher than the preeclampsia group screened in the same duration. We believe that the reason is the admissions from nearby regions. No matter how early and proper is the diagnosis, HELLP syndrome and severe preeclampsia are still gestational complications causing maternal and fetal mortality.

Conflicts of Interest: No conflicts declared.

\section{References}

1. Sibai B, Dekker G, Kupferminc M. Pre-eclampsia. Lancet 2005;365:785-99.
2. Uzan J, Carbonnel M, Piconne O, Asmar R, Ayoubi JM. Pre-eclampsia: pathophysiology, diagnosis, and management. Vasc Health Risk Manag 2011;7:467-74.

3. Gezginc K, Acar A, Gezginc ST, Okur N, Akyürek C. The evaluation of preeclamptic pregnancies in our clinic. [Article in Turkish] Süleyman Demirel Üniversitesi Tip Fakültesi Dergisi 2003;10:1-3.

4. Norwitz ER, Hsu CD, Repke JT. Acute complications of preeclampsia. Clin Obstet Gynecol 2002;45:308-29.

5. Sibai BM. The HELLP syndrome (hemolysis, elevated liver enzymes, and low platelets): much ado about nothing. Am J Obstet Gynecol 1990;162:311-6.

6. Padden MO. HELLP syndrome: recognition and perinatal management. Am Fam Physician 1999;60:829-36.

7. Deen ME, Ruurda LG, Wang J, Dekker GA. Risk factors for preeclampsia in multiparous women: primipaternity versus the birth interval hypothesis. J Matern Fetal Neonatal Med 2006;19:79-84.

8. Sibai BM, Ramadan MK, Usta I, Salama M, Mercer BM, Friedman SA. Maternal morbidity and mortality in 442 pregnancies with hemolysis, elevated liver enzymes, and low platelets (HELLP syndrome). Am J Obstet Gynecol 1993;169:1000-6.

9. Magann EF, Chauhan SP, Naef RW, Blake PG, Morrison JC, Martin JN Jr. Standard parameters of preeclampsia: can the clinician depend upon them to reliably identify the patient with the HELLP syndrome? Aust $\mathrm{N}$ Z J Obstet Gynaecol 1993;33:122-6.

10. Haram K, Svendsen E, Abildgaard U. The HELLP syndrome: clinical issues and management. A review. BMC Pregnancy and Childbirth 2009;9:8.

11. Barton JR, Sibai BM. Diagnosis and management of hemolysis, elevated liver enzymes, and low platelets syndrome. Clin Perinatol 2004;31:807-33.

12. Gul A, Cebeci A, Aslan H, Polat I, Ozdemir A, Ceylan Y. Perinatal outcomes in severe preeclampsia-eclampsia with and without HELLP syndrome. Gynecol Obstet Invest 2005;59:113-8.

13. Sibai BM, Ramadan KM. Acute renal failure in pregnancies complicated by hemolysis, elevated liver enzyme, low platelets. Am J Obstet Gynecol 1993;168:1682-90.

14. Celik C, Acar A, Gonenc O, Görkemli H, Çapar M, Akyürek C. The asses the cases with HELLP syndrome. [Article in Turkish] Süleyman Demirel Üniversitesi Tip Fakültesi Dergisi 1999;6:11-4.

15. Sibai BM. Diagnosis, controversies, and management of the syndrome of hemolysis, elevated liver enzymes, and low platelet count. Obstet Gynecol 2004;103:981-91.

16. Baxter JK, Weinstein L. HELLP syndrome: the state of the art. Obstet Gynecol Surg 2004;59:838-45. 